\title{
Mechanisms for Harmonizing the Sustainable Development of Kuzbass as a Resource Region
}

\author{
Yuri Fridman ${ }^{1}$, Ekaterina Loginova ${ }^{1}$, and Galina Rechko ${ }^{1,2, *}$ \\ ${ }^{1}$ Institute of Economics and Industrial Engineering of the Siberian Branch of the Russian Academy of \\ Sciences, 630090, Novosibirsk, Russian Federation \\ ${ }^{2}$ T.F. Gorbatchev Kuzbass State Technical University, 650000, Kemerovo, Russian Federation
}

\begin{abstract}
The article views the problems related to harmonizing the development of a resource area. Kemerovo Oblast - Kuzbass is selected as the object of this study. We point out that, in the absence of consensus between authorities and business concerning the prospective development of the region, its economy may decay even despite obvious success in the fundamental industry, namely coal mining. It is strategically important for Kuzbass to create an efficient infrastructure for transforming the development of the coal industry into the economy-wide development of the region. Taking into account best international harmonization practices, we propose a conceptual system of mechanisms aimed at coordinating the interests of the commodity-driven business and the resource area built on the 'common grounds' shared by the coal industry and Kemerovo Oblast. The concept in question relies on the need to introduce business models to the industry management that would harmonize with the interests of the territory. At the same time, the territory should start to build a new economy by creating new standards that would establish requirements for doing business.
\end{abstract}

\section{Introduction}

A major issue for the majority of Russian regions producing raw materials (resource regions) is the business and authorities disagreeing over how the area should develop. This causes it to decay even despite obvious success in fundamental industries (e.g. [1]), as is happening today in Kemerovo Oblast-Kuzbass, the center of the Russian coal industry. Unfortunately, neither at the national nor regional levels is there any holistic understanding of how to practically transform the successful development of the primary sector into economy-wide development. Among the reasons is the lack of tools for converting the effects of mineral resources development into economic system's productivity that would be understandable to all actors in the regional economic space.

In our opinion, a way out of this situation in Kuzbass is, first of all, to reset the entire system of relations between the coal industry and the area at the 'entrance' to the region. The second solution is to introduce principles of the harmonious development of a resource region in Kemerovo Oblast, which is crucial as part of improving the territory's

\footnotetext{
* Corresponding author: rgn.vt@kuzstu.ru
} 
competitiveness. This purpose requires identifying 'common grounds' between the coal industry and the region, as well as setting out conflict resolution mechanisms, which will allow forming an effective model for the long-term development of Kuzbass.

\section{Materials and Methods}

International scholars began studying harmonization problems in the early 1990s. This period signified the emergence of the famous 'resource curse' theories [2, 3]. Then, thanks to the success stories featuring the resource economies in Canada, Australia, Norway, and others, works appeared proving that the resource curse is not inevitable [4]. For one, global experience shows that even now the mining industry is fully capable of stimulating growth in national and regional economies [5]. Chile may serve as an example: for twenty years this country remained the fastest growing one in South America.

Yet, there are no consolidated mechanisms for market self-regulation that would ensure the harmony of interests between business and resource regions. Each country solves these problems on its own. In Russia, almost every region, including Kemerovo Oblast, has gained experience in using different tools for interaction between business and the area. In most cases, they are based on informal agreements between regional authorities and business. But our studies (e.g. [6, 7]) and practices in Kuzbass show that, under certain conditions, authorities and business can find interest coordinating mechanisms to harmonize the development of the resource area [8] (Figure 1).

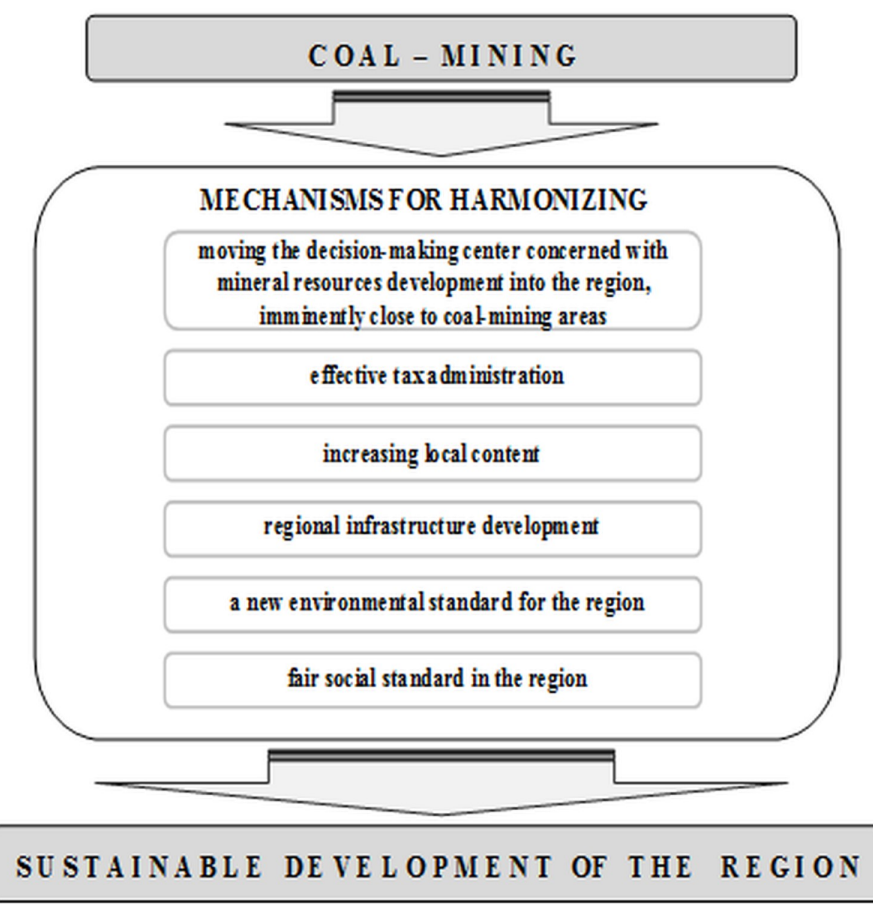

Fig. 1. Fragment of the harmonization model for the development of the primary industry and the area: harmonization mechanisms. 


\section{Results and Discussion}

The advances of the coal industry in Kuzbass are obvious. Several factors have led to the development of this business in Kemerovo Oblast:

- In 1994-2016 the Russian coal industry underwent an avalanche of elaborate restructuring. Having the World Bank, the International Monetary Fund, and the Hoover Institute at their side, Russian experts carried out a plan to 'softly' eliminate inefficient coal capacity. Over ten years, the Russian coal sector experienced changes in the mining technology, the management system, and the funding vehicle;

- The vast majority of coal enterprises, despite the change of ownership, are managed by highly skilled professionals well aware of the particular characteristics of the Kuzbass fields;

- A big portion of coal-mining facilities in the region have fallen under the control of large vertically integrated companies (SUEK, EVRAZ, MMK, Mechel, UMMC), which has facilitated promoting Kuzbass coal in global markets and reduced the dependence of coal production on coal consumption decline within Russia;

- against the backdrop of the oil and gas booms, coal yielded relatively low profits; as a result, the Russian government simply did not pay much attention to it in terms of the tax burden;

- Although in the early 2000s Kemerovo Oblast announced the strategic significance of the coal industry, it put forward too lenient criteria for its development regarding several 'common grounds' simultaneously.

In the period between 2007 and 2017, the coal industry and the whole region showed very 'impressive' development results: coal production grew 1.3-fold, gross regional product decreased by 8 percent, real gross wages increased by 18 percent, real household disposable income dropped by 24 percent.

The issue of Kuzbass harmonization as a resource region is of particular relevance now, since the further growth of the coal industry in the region is becoming a nationwide project. For the next 15 years, Kemerovo Oblast will need to increase coal production by no less than 100 million tons against 255.3 million tons produced in 2018.

Kuzbass needs to create an effective infrastructure for transforming the development of the coal industry into regional development based on the principles of an inclusive economy [9] by involving all economic actors in the decision-making process, together with distributing risks and responsibilities among them. The following mechanisms should contribute to this:

- Moving the decision-making center concerned with mineral resources development into the region, imminently close to coal-mining areas.

Such an approach, in our opinion, will make it possible to consider the interests of the territory and its residents to the greatest extent. Formally, it can be expressed, for instance, in using the two-man rule when issuing mining permits. Kuzbass authorities insist on bringing this practice back to the coal industry. When looking at this issue more broadly and taking into account the experience of resource-rich countries, we are talking about introducing a strategic planning system in the development of the region's mineral and raw materials (which requires to create a long-term development program for the coal industry in Kemerovo Oblast). The system is supported by the region and subsoil users signing 'licensing agreements' even before they start coal mining. Such a document should contain mechanisms for transferring a part of the value obtained while developing a field towards the territory, specify how a subsoil user increases employment opportunities for the residents and provides comfortable living conditions inside the region, which should include improving social services and solving environmental problems associated with the mining industry; 
- Effective tax administration.

At the moment, the main formal tool for transforming coal-generated financial resources into territorial development is taxes. The taxation of the coal industry in Russia is based on gross indicators (revenue, production, and export of coal products). This practice is typical of developing countries. It benefits from the relative ease of administration and guaranteed tax revenues to the budget. What is different is that the essential portion of these revenues consists of the income tax, whose value depends on fluctuations in world markets due to the export-oriented model of the coal business in Russia. We think the coal industry requires a change in fiscal management so as to stimulate business to invest, assume high risks of developing new deposits but also look to the long term, nonetheless. For one, Kuzbass may become a platform for a tax experiment on the financial result of coal enterprises. Moreover, it is equally important to resolve the issue of redistributing tax deductions from the coal industry in favor of the resource region itself;

- Increasing local content.

Synergy achieved from the fundamental industry development may be called the main condition for harmonizing the development of the resource area. This is due in no small part to the amount of local content in production and the involvement of local business in supply chains of goods and services for mining, the region's anchor industry. Local content in Kemerovo Oblast today is currently quite low, below 10 percent, according to our estimates. Within Kuzbass coal companies' annual purchases at about 400 billion rubles, products of regional origin amount to only 40-45 billion rubles. The amount of local content in the region is not governed by licensing agreements or regional legislation. However, large coal mining companies in Kuzbass use the world's best technology, while global leading mining equipment manufacturers strive to promote their products on the region's market. It creates prerequisites for the rapid growth of localization thanks to the developing service sector. Another promising trend is related to the fuel supply of coal mining enterprises: investment activity in oil refining should be accelerated to start producing diesel fuel for the coal industry. Besides, it is definitely important to adapt regional research centers to the demands of the modern coal business in mining, transportation, and processing of solid fuels;

- Regional infrastructure development.

High-quality infrastructure is traditionally considered mandatory for the efficient development of minerals, the investment attractiveness of the resource area (e.g. [10]) and its subsequent improvement. Due to the historical peculiarities of its exploration, Kuzbass differs from other Siberian regions by having a rather strong infrastructure in general (transport systems, power network, etc.). Nevertheless, when mining new deposits in Kemerovo Oblast, businesses face an increase in development costs, related to the preparation and operation of the infrastructure necessary, in particular, to supply energy to enterprises, transport coal by road and rail, etc. The high wear rate of most municipal infrastructure all over the region remains a problem. In the long term, infrastructure constraints might inhibit the development of Kemerovo Oblast. We think a way out may be to actively involve the commodity business in large infrastructure projects on the principles of public-private partnership and then to share infrastructure facilities created in so doing; - A new environmental standard for the region.

Coal mining is among the top 10 industries with the greatest negative impact on the environment. With growing production and beneficiation, the technogenic load of the coal industry on Kemerovo Oblast will definitely continue to rise, which becomes a serious risk for the region and coal business. Kuzbass authorities have put forward an idea of establishing a regional environmental standard that, according to open sources, should include a sanitary protection zone (at least a thousand meters from open-pit coal mines), local authorities hearings when issuing permits for natural resource management, 
relocations from subsided surfaces, and other services. In our opinion, an environmental standard for Kuzbass should be an active and efficient mechanism for coordinating interests between the territory and coal companies. We believe that such a document should follow advanced environmental monitoring and contain not only standards for the regional coal industry but also incentives to practicing environmental consciousness and transparency, introducing the best available technologies, promoting environmental insurance, biodiversity offsetting, etc.;

- Fair social standard in the region.

Employment rate and wage conditions are important indicators showing how much the territory 'feels' the industry's presence. Increased labor productivity in the coal industry, on the one hand, leads to a reduction in employment; on the other, no adequate wage growth is observed in Kuzbass. The authorities are trying to influence the coal business by tightening social measures (for example, settling people in the sanitary protection zones of coal enterprises at the companies' expense). However, the efforts undertaken are clearly not enough: they do not solve the problem of encouraging human capital investment (education, health, etc.) in Kemerovo Oblast. It is indispensable to envisage an up-to-date fair 'social standard for Kuzbass' that would regulate the obligations of the base materials sector to the local community (wage levels, local content in employment, direct social obligations to the municipal entity where coal is being mined, satisfying the interests of small indigenous peoples, etc.). The fulfillment of these standards should also be part of a license agreement between the resource area and the subsoil user.

\section{Conclusion}

Thus, the proposed mechanisms for harmonizing the interests of authorities and business rely, on the one hand, on introducing business models in the Kuzbass coal industry management that cater to the needs of the territory. On the other hand, they come from formalizing and standardizing approaches towards interaction between Kemerovo Oblast and the resource business. In other words, relations between the region (government, society) and the industry (business) should base upon a clear set of rules for 'the game', which will help resolve conflicts and mitigate certain immediate risks inside the coal industry [11] and the resource area.

\section{References}

1. V. Basareva, N. Mikheeva, Regional Research of Russia, 8:2, 184 (2018)

2. J. Sachs \& A. Warner, National Bureau of Economic Research Working paper, 5398 (1995)

3. P. Van Der, Journal of Economic Literature, 49:2, 326 (2011)

4. De Ferranti, G. Perry, D. Lederman \& W. Maloney, From Natural Resources to the Knowledge Economy (IBRD, Washington, 2002)

5. V. Kondrat'ev, World Economy \& International Relations, 60:1, 41 (2016)

6. Iu. Fridman, G. Rechko, Problems of Economic Transition, 55:6, 30 (2012)

7. Yu. Fridman, G. Rechko, E. Loginova, Journal of Mining Science, 51:5, 924 (2015)

8. V. Kryukov, A. Sevastyanova, A. Tokarev, V. Shmat, Economy of region, 13:1, 93 (2017)

9. Fraser Institute Annual Survey of Mining Companies (British Columbia Press., Vancouver, 2014) 